\title{
OPEN Modeling cometabolism of hexavalent chromium by iron reducing bacteria in tertiary substrate system
}

\author{
Shivangi Upadhyay \& Alok Sinha ${ }^{凶}$ \\ In this study, a bacterial strain Serratia sp. was employed for the reduction of synthetically prepared \\ different concentration of $\mathrm{Cr}(\mathrm{VI})$ solution (10, 25, 40, 50 and $100 \mathrm{mg} / \mathrm{L})$. Cometabolism study have \\ been carried out in the binary substrate system as well as in the tertiary substrate system. The results \\ revealed that when glucose was added as a co-substrate, at low $\mathrm{Cr}(\mathrm{VI})$ concentration, complete \\ reduction was achieved followed by increased biomass growth, but when $\mathrm{Cr}(\mathrm{VI})$ concentration was \\ increased to $100 \mathrm{mg} / \mathrm{L}$, the reduction decline to $93 \%$. But in presence of high carbon iron filings (HCIF) \\ as co-substrate even at higher $\mathrm{Cr}(\mathrm{VI})$ concentration i.e. $100 \mathrm{mg} / \mathrm{L}, 100 \%$ reduction was achieved and \\ the cell growth continued till $124 \mathrm{~h}$. The study was illustrated via Monod growth kinetic model for \\ tertiary substrate system and the kinetic parameters revealed that the HCIF and glucose combination \\ showed least inhibition to hexavalent chromium reduction by Serratia sp.
}

A prevalent environmental pollutant chromium, is widely used in different industries such as cement, tannery, smelting industries and in electroplating ${ }^{1}$ for various purposes ${ }^{2,3}$. The presence of chromium mostly occurs in two different oxidation form i.e. hexavalent and trivalent one that signifies their toxicity. Amongst the two, the former one is highly toxic because of its higher solubility ${ }^{4}$ penetrable capability through biological membranes, highly mobile and have carcinogenic, mutagenic property ${ }^{5}$ and also intramolecular nucleic acid interaction, whereas, the latter one is less toxic, act as an important element in trace amount ${ }^{5}$ and important in metabolism of carbohydrate and lipids ${ }^{6}$. Having mutagenic and carcinogenic effects on humans such as internal hemorrhage, nausea, dermatitis, asthma, liver and kidney damage ${ }^{7}$ based on this, the powerful pollutant has been recognized as type I carcinogen and been further assigned the limit of total chromium presence in drinking water to less than $0.1 \mathrm{mg} \mathrm{L}^{-1}$ by the International Agency for Research on Cancer (IARC) and the United States Environmental Protection Agency (USEPA) respectively ${ }^{8}$. Cr(VI) reduction through conventional methods like chemical reduction, reverse osmosis, ion exchange, precipitation, adsorption and coagulation have major drawbacks including generation of secondary pollutants and high operating cost ${ }^{9-11}$. High carbon iron filings (HCIF) may offer the best choice as a reactive media due to its non-toxicity, low cost and availability. HCIF is capable of adsorbing, reducing and transforming many chlorinated hydrocarbons, heavy metals, and nitroaromatic compounds. A study by ${ }^{10}$ demonstrated the use of HCIF in Cr(VI) reduction and the results revealed that $\mathrm{Cr}(\mathrm{VI})$ adsorption to graphite inclusions that are present on HCIF had a great role in reduction of aqueous concentration. An experiment conducted by ${ }^{12}$ for effective removal of $\mathrm{Cr}(\mathrm{VI})$ from wastewater using ultrasonic pretreated sludge derived stable magnetic active carbon. The synthesized UMC had a high proportion of ZVI. Both the ZVI and carbon in the UMC was disclosed to be the domain electron donors for treating $\mathrm{Cr}(\mathrm{VI})$-containing wastewater having concentration $2 \mathrm{mg} / \mathrm{L}$. Another method of $\mathrm{Cr}(\mathrm{VI})$ removal was adopted by ${ }^{13}$ using Fluorine and nitrogen co-doped magnetic carbons (FN-MCs) which showed good removal efficiency. But the above mentioned methods have certain shortcomings like generation of secondary pollutants and high operational cost. An ecofriendly approach towards treatment of hexavalent chromium is biological reduction just before the disposal of wastewater into the environment by industries ${ }^{14}$. There are a number of microorganisms involved in the process of reduction and has been proved to be effective in this context ${ }^{15-18}$. But some of the forces hinders the overall process of microbial reduction. Focus should be given on reducing the hindrance such as adequate amount of nitrogen and carbon source, suitable $\mathrm{pH}$ and temperature suitability of wastewater, and the other toxic heavy 
metals presence in wastewater. These problems create difficulty for the non-indigenous microorganisms to effectively treat the wastewater.

Cometabolic degradation has been found to be eco-friendly and economically feasible in the process of treating recalcitrant compounds ${ }^{19}$, and coking wastewater (CWW) treatment ${ }^{20}$. Many studies stated that when phenol was used as the cometabolic substrate, the degradation efficiency of $p$-nitrophenol ${ }^{21}$, carbazole ${ }^{22}$ and 4 -chlorophenol ${ }^{23}$ increased. In cometabolism, metabolic substrates such as glucose, methyl alcohol are sufficient source of carbon and energy for microbes to grow. These substrates induces enzymes synthesis that accelerates metabolism of growth and non-growth substrates, producing $\mathrm{NADH}$ as electron donor in metabolic pathway and subsequently these metabolites take part in degradation of various compounds ${ }^{24}$. Little attention has been given to cometabolic reduction of hexavalent chromium.

Earlier in our previous work, Serratia sp. was able to reduce different range of hexavalent chromium. But the inhibition effect of hexavalent chromium was higher for Serratia sp. As a result, the growth of the bacterial species was hindered after few $\mathrm{hr}^{25}$. To reduce the inhibitory effect of $\mathrm{Cr}(\mathrm{VI})$ on the bacteria, this study demonstrates the use of glucose and high carbon iron filings (HCIF) as cometabolic substrates for microbial reduction of $\mathrm{Cr}(\mathrm{VI})$.

\section{Materials and methods}

Chemicals. The chemicals, reagents and microbial media were of pure grade. $\mathrm{Cr}(\mathrm{VI})$ standard solution of $1000 \mathrm{mg} \mathrm{L}^{-1}$ have been prepared by mixing $\mathrm{K}_{2} \mathrm{CrO}_{7}$ in Milli Q water. For measuring hexavalent chromium concentration, Diphenyl carbazide (DPC) solution (0.25\%) was prepared by dissolving it in $95 \%$. Microbes were grown in broth media of Lureia Bertani (Hi-Media India). Glucose (Rankem, purity 99.0\%) were used as cometabolic substrates.

Experimental process. Bacterial strain was isolated from iron ore mines as discussed in the work done previously by ${ }^{25}$. Commercially available cast iron rod was chipped on a lathe machine and was brought into iron filings in a dough-sized ball mill. HCIF thus obtained were washed with $\mathrm{N}_{2}$ sparged $1 \mathrm{~N} \mathrm{HCl}$ for $4-5$ times so that the organic material adsorbed on HCIF surface during chipping process may be removed as well as the reactivity of HCIF may be enhanced. Afterwards, HCIF was washed again with $\mathrm{N}_{2}$ sparged milli Q water for 10-12 times to remove excess HCl. Later, moisture content of HCIF was removed by washing with $95 \%$ acetone and HCIF were dried in $\mathrm{N}_{2}$ atmosphere in a vacuum desiccator and then used for the experimental purpose. Cometabolism studies were conducted for enhancing the reduction capacity of the HCIF-bacteria system. Batch experiments were conducted with two different combination (i) Binary system containing bacteria and glucose $(1 \mathrm{~g} / 250 \mathrm{~mL})$ and (ii) Tertiary system with bacteria, HCIF $(1 \mathrm{~g} / 250 \mathrm{~mL})$ and glucose $(1 \mathrm{~g} / 250 \mathrm{~mL})$ having different $\mathrm{Cr}(\mathrm{VI})$ concentration $(10,25,40,50$, and $100 \mathrm{mg} / \mathrm{L})$ in an incubator shaker at $35^{\circ} \mathrm{C}$ and $120 \mathrm{rpm}$. Samples were taken at every $12 \mathrm{~h}$ and analysis of $\mathrm{Cr}(\mathrm{VI})$, biomass, and glucose concentration was measured by Uv-Vis spectrophotometer at 540,600 and $510 \mathrm{~nm}$, respectively. Samples were taken at regular time and concentration of $\mathrm{Cr}(\mathrm{VI})$, bacterial growth, and glucose was measured by Uv-Vis spectrophotometer at wavelength of 540, 600 and $510 \mathrm{~nm}$ respectively.

Rate kinetics model. The pseudo first and second order was applied to define the kinetic degradation of microbe's kinetics of hexavalent chromium which is given below:

$$
C=C_{O e^{-k t}}
$$

where, $\mathrm{C}$ is the concentration at any time, initial concentration is denoted as $\mathrm{C}_{\mathrm{O}}$, $\mathrm{k}$ is the pseudo first-order rate constant $\left(\right.$ day $\left.^{-1}\right)$, and reaction time is denoted by $t$.

Kinetics of microbial growth in system containing single substrate. Growth kinetics in single system comprises of bacteria and glucose and chromium exposure. In a batch system, the specific growth rate of a cell, $\mu\left(\mathrm{h}^{-1}\right)$ is defined as

$$
\mu=\frac{1}{X} \frac{d X}{d t}=\frac{d \ln X}{d t}
$$

where, $\mu$ is calculated at the exponential phase of the growth curve. $\mathrm{X}$ is the concentration of cell in either cell number at time ' $\mathrm{t}$ ' based on the viable counts $(\mathrm{CFU} / \mathrm{mL}$ ) or in either $\mathrm{g} / \mathrm{L}$ (dry basis). The specific growth rate of cell on single substrate is expressed in terms of $\mu$ in Eq. (2), which is a function of concentration of resource. The Haldane Andrew model was applied here in the single substrate system as it has its wide use in representing the growth kinetics of single substrate:

$$
\mu=\mu \max S /\left(S+\frac{S^{2}}{K_{I}}+K_{S}\right)
$$

where, $\mu_{\max }$ is the maximum specific growth rate $\left(\right.$ day $\left.^{-1}\right)$, substrate concentration is defined by the term 'S' and $\mathrm{K}_{\mathrm{s}}$ is the substrate affinity constant $(\mathrm{mg} / \mathrm{L})$.

Growth kinetics in tertiary substrate system. To stimulate Co-metabolism, for the cell growth on mixtures of substrate, various models have been proposed. In this study, Monod model used in binary substrate system $^{19}$ was modified to tertiary substrate system for the analysis of growth kinetic parameters. The equation for the specific growth rate on tertiary inhibitory substrates was as follows: 


$$
\mu=\frac{\mu_{\max C} S_{C}}{K_{S C}+S_{C}+K_{2 C} S_{P}+K_{3 C} S_{h}+K_{4 C} S_{P} S_{h}}+\frac{\mu_{\max P} S_{P}}{K_{S P}+S_{C}+K_{2 P} S_{C}+K_{3 P} S_{h}+K_{4 P} S_{C} S_{h}}+\frac{\mu_{\operatorname{maxh}} S_{h}}{K_{S h}+S_{h}+K_{2 h} S_{C}+K_{3 h} S_{P}+K_{4 h} S_{C} S_{P}}
$$

where the subscripts $\mathrm{C}, \mathrm{P}$, and h represents glucose as a carbon source, $\mathrm{Cr}(\mathrm{VI})$ and HCIF respectively. The physical meaning of $K_{s}$ and $\mu_{\max }$ is basically the same as described in Eq. (4) and obtained in single system. $\mu_{\operatorname{maxC}} \mathrm{S}_{\mathrm{C}}$, denotes maximum specific growth rate in presence of glucose which was obtained from the results of growth kinetics in binary substrate system, Similarly, $\mu_{\max } \mathrm{S}_{\mathrm{P} \text {, is }}$ denoted by maximum specific growth rate in presence of chromium and $\mu_{\operatorname{maxh}} S_{\mathrm{h}}$, is denoted by maximum specific growth rate in presence of HCIF which were obtained from the model fitting of growth kinetics in binary substrate system. Equation (4) implies that there are kinetic interactions between all the three substrates if all $\mathrm{K}_{2 \mathrm{i}}, \mathrm{K}_{3 \mathrm{i}}$, and $\mathrm{K}_{4 \mathrm{i}}(\mathrm{i}=\mathrm{C}, \mathrm{P}$ and $\mathrm{h})$ are not equal to zero. Here, the literal meaning of $K_{2}, K_{3}$ and $K_{4}$ is described below:

$K_{2 C} S_{P}=$ Inhibition of glucose in the presence of $\mathrm{Cr}(\mathrm{VI})$

$K_{3 C} S_{h}=$ Inhibition of glucose in the presence of HCIF

$K_{4 C} S_{P} S_{h}=$ Inhibition of glucose in the presence of $\mathrm{Cr}(\mathrm{VI})$ and $\mathrm{HCIF}$

$K_{2 P} S_{C}=$ Inhibition of $\mathrm{Cr}(\mathrm{VI})$ in the presence of glucose

$K_{3 P} S_{h}=$ Inhibition of $\mathrm{Cr}(\mathrm{VI})$ in the presence of $\mathrm{HCIF}$

$K_{4 P} S_{C} S_{h}=$ Inhibition of $\mathrm{Cr}(\mathrm{VI})$ in the presence of glucose and HCIF

$K_{2 h} S_{C}=$ Inhibition of HCIF in the presence of glucose

$K_{3 h} S_{P}=$ Inhibition of HCIF in the presence of $\mathrm{Cr}(\mathrm{VI})$

$K_{4 h} S_{C} S_{P}=$ Inhibition of HCIF in the presence of glucose and $\mathrm{Cr}(\mathrm{VI})$.

Statistical analysis. The experiments have been performed in triplicates and mean of three samples were taken. To determine the mean and standard deviation of the data sets, XLSTAT package of Microsoft excel 2013 was used. One way ANOVA followed by Duncan's post hoc test was performed to determine the biomass concentration of the test isolate in absence and presence of chromium.

\section{Results and discussion}

Reduction of $\mathrm{Cr}(\mathrm{VI})$ in batch reactors in the presence of cometabolic substrate (HCIF and glucose). The strain isolated was identified as Serratia sp. ${ }^{25}$. It was used in our previous study for reduction of different concentration of $\mathrm{Cr}(\mathrm{VI})$ in two different ways, i.e. one by the strain alone and the other by co-assistance of HCIF with the strain. This study was performed to demonstrate the cometabolic effect of substrate on reduction of hexavalent chromium. Cometabolism study was conducted to evaluate the cometabolic activity of Serratia sp. in two different sets i.e. when glucose was added $(1 \mathrm{~g} / 250 \mathrm{~mL})$ to batch reactors containing $\mathrm{Cr}$ (VI) and bacteria (Set 1) and when glucose was added to batch reactors containing Cr(VI), bacteria and HCIF (Set 2) for the reduction of hexavalent chromium by Serratia sp. The biomass concentration, $\mathrm{Cr}(\mathrm{VI})$ concentration and glucose concentration was measured in the two sets. Figure $1 \mathrm{~A}, \mathrm{~B}$, shows the biomass abundance at different concentration of $\mathrm{Cr}(\mathrm{VI})(10,25,40,50$, and $100 \mathrm{mg} / \mathrm{L})$ when glucose was added as cometabolic substrate in both the sets. The results of Set 1 indicated that when glucose was added to batch reactors containing only bacteria and $\mathrm{Cr}(\mathrm{VI})$, the bacterial growth was highest for $10 \mathrm{mg} / \mathrm{L} \mathrm{Cr}(\mathrm{VI})$ solution, the growth increased till $50 \mathrm{~h}$ and after which it started declining. The lesser the concentration of $\mathrm{Cr}(\mathrm{VI})$, the higher was the bacterial growth. For $25 \mathrm{mg} / \mathrm{L} \mathrm{Cr}(\mathrm{VI})$ concentration, the growth was highest at $24 \mathrm{~h}$ and then it declined and lasted till $60 \mathrm{~h}$. In case of $50 \mathrm{mg} / \mathrm{L}$ of $\mathrm{Cr}(\mathrm{VI})$ concentration, the biomass growth was very low in comparison to other concentrations. However, slight increase in growth was observed at $24 \mathrm{~h}$. In case of $100 \mathrm{mg} / \mathrm{L}$ of $\mathrm{Cr}(\mathrm{VI})$ concentration, the bacteria attained its $\log$ phase at $50 \mathrm{~h}$ and after that the stationary phase was observed. In this case the lag phase increased with increase in initial $\mathrm{Cr}(\mathrm{VI})$ concentration which may be due to the inhibitory effect of $\mathrm{Cr}(\mathrm{VI})$ on the growth of microorganism. At high concentrations, the inhibitory effect increased due to the fact that a fixed amount of inoculum was used for all different concentration of $\mathrm{Cr}(\mathrm{VI})$. In the second experimental set (Set 2), it was found out that at all the different concentration of $\operatorname{Cr}(\mathrm{VI})(10,25,40,50$ and $100 \mathrm{mg} / \mathrm{L})$ the log phase started after $50 \mathrm{~h}$ and the cell doubling continues till $85 \mathrm{~h}$. After this the decline in biomass concentration was observed. The results from the study indicated that when only glucose acted as co-metabolic substrate, the biomass growth lasted till $60 \mathrm{~h}$ but when glucose was added to the HCIF and bacterial set, the bacterial growth continues till $120 \mathrm{~h}$. This may be due to the reason that, HCIF may be acting as a co-metabolic substrate in enhancing the bacterial growth along with the glucose. HCIF too acts as a source of growth to bacteria like glucose, when supplied with low dosing ${ }^{26}$.

Experiments were conducted for evaluating the reduction in $\mathrm{Cr}(\mathrm{VI})$ concentration with respect to time for the same experimental set as discussed above (Set 1 and Set 2). For Set 1, the results indicated that complete reduction of $10 \mathrm{mg} / \mathrm{L}$ and $25 \mathrm{mg} / \mathrm{L} \mathrm{Cr}(\mathrm{VI})$ concentration was achieved at $40-50 \mathrm{~h}$ and $75-76 \mathrm{~h}$, respectively, and similarly for $40 \mathrm{mg} / \mathrm{L}$ and $50 \mathrm{mg} / \mathrm{L} \mathrm{Cr}(\mathrm{VI})$ concentration, the complete reduction was achieved at $80 \mathrm{~h}$. But in case of $100 \mathrm{mg} / \mathrm{L} \mathrm{Cr}(\mathrm{VI})$ concentration, complete reduction was not achieved till $90 \mathrm{~h}$ of experiment (Fig. 2A). At lower concentration of $\mathrm{Cr}(\mathrm{VI})(10$ and $25 \mathrm{mg} / \mathrm{L})$ the maximum reduction was achieved in less time. The reason may be due to the presence of high concentration gradient of $\mathrm{Cr}$ in the solution, makes it more difficult to reduce completely ${ }^{27}$. Although glucose was added as a co-metabolic substrate for enhancing the activity of microbes, complete reduction efficiency was not achieved.

The results from the second experimental set (Set 2) showed that for 10 and $25 \mathrm{mg} / \mathrm{L} \mathrm{Cr}$ (VI) concentration, the reduction was initiated after $15 \mathrm{~h}$ and complete reduction was achieved between 30 and $40 \mathrm{~h}$. In case of 40 and $50 \mathrm{mg} / \mathrm{L} \mathrm{Cr}(\mathrm{VI})$ concentration, the complete reduction was achieved at $60 \mathrm{~h}$. For $100 \mathrm{mg} / \mathrm{L} \mathrm{Cr}(\mathrm{VI})$ concentration, 


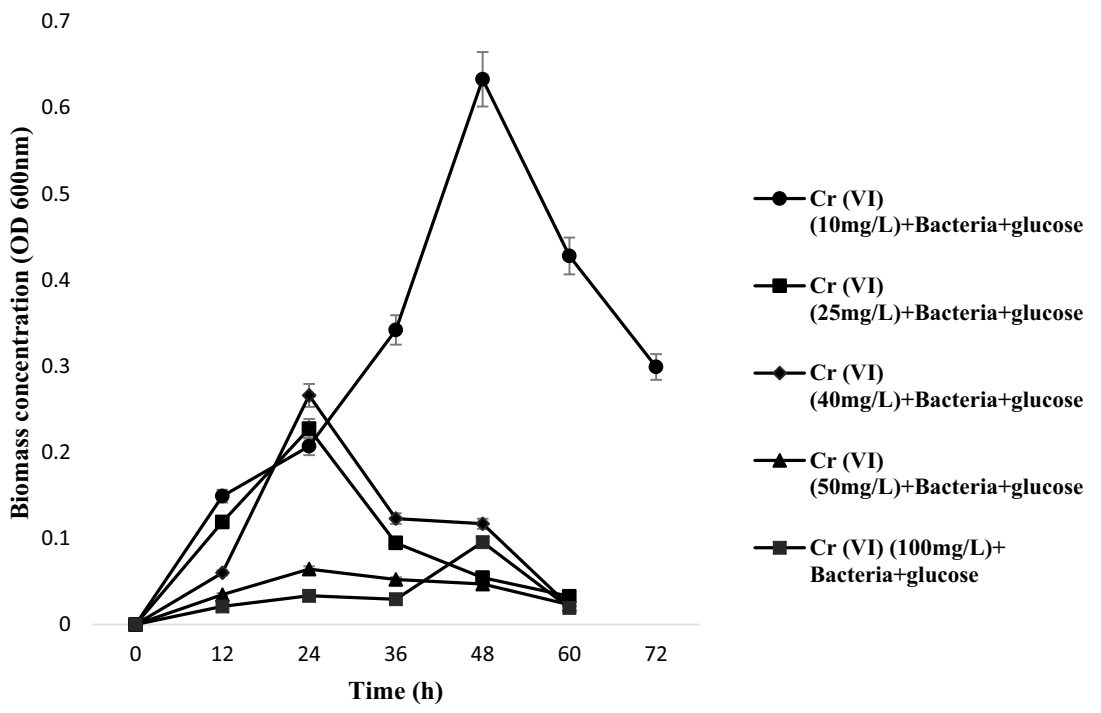

(A)

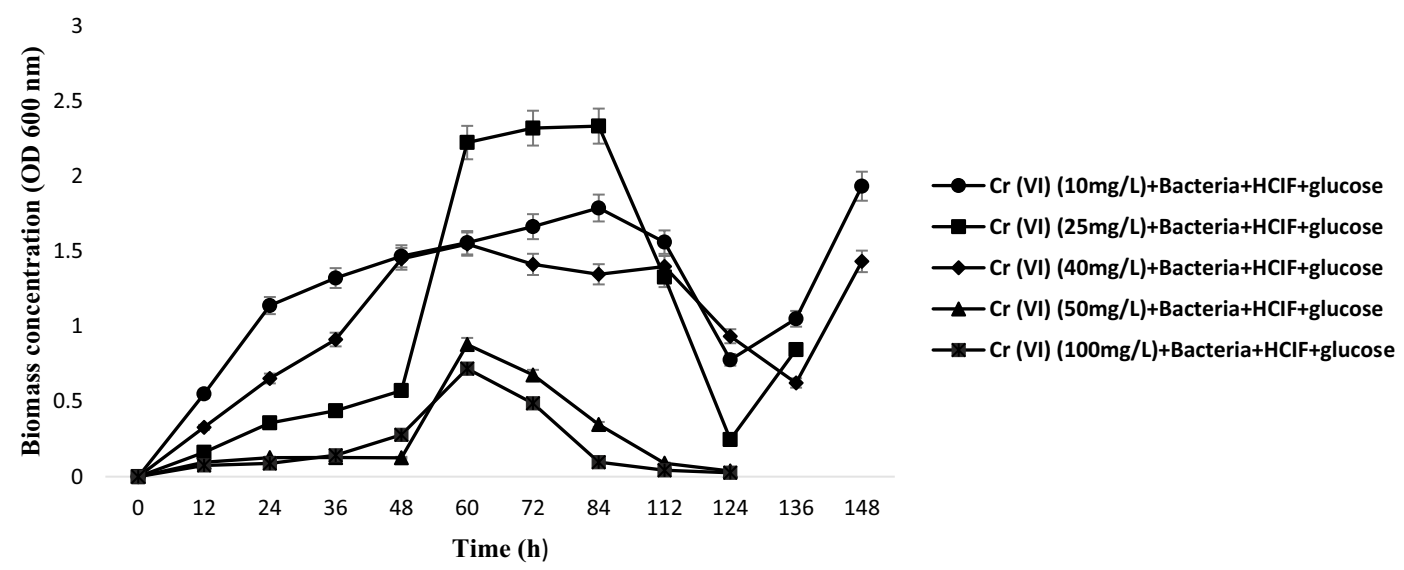

(B)

Figure 1. Temporal variation in biomass concentration with the (A) binary substrate system (B) tertiary substrate system.

the reduction was initially slow but after $70 \mathrm{~h}$ the reduction was faster and it was completely achieved at $120 \mathrm{~h}$ (Fig. 2B). This result was better in comparison to the first experimental set. The results clearly indicated that HCIF was also acting as a co-metabolic substrate in enhancing the reduction efficiency of $\mathrm{Cr}(\mathrm{VI})$. The possible mechanism behind improved $\mathrm{Cr}(\mathrm{VI})$ reduction is due to coexistence of Serratia sp. with HCIF which helped in reduction of $\mathrm{Cr}(\mathrm{VI})$ as well as helped in maintaining the longevity of HCIF. Secondly the strain reduces Fe(III) to $\mathrm{Fe}(\mathrm{II})$, resulting in higher dissolved $\mathrm{Fe}(\mathrm{II})$ and thus maintaining the structured morphology of HCIF by removing the passivated ferric precipitates on iron surface. It has been confirmed by ${ }^{28}$ also that in the presence of NZVI, the $\mathrm{Cr}(\mathrm{VI})$ reduction efficiency by strain DIRB HS01could be improved. Similar type of cometabolic study has been performed by ${ }^{29}$ in which cometabolic degradation of blended biodiesel by a fungal strain Monilliella wahieum $Y 12^{\mathrm{T}}$ was carried out. The results showed that degradation of petroleum diesel (ULSD) was enhanced when the fungal strain was used with biodiesel. Another experiment conducted by ${ }^{30}$ demonstrated the effect of hydroxypropyl- $\beta$-cyclodextrin on cometabolism of phenol and phenanthrene by Chryseobacterium sp. The results stated that cometabolic activity of phenol and hydroxypropyl- $\beta$-cyclodextrin accelerated the degradation of phenol and had great phenanthrene removal rate. Addition of hydroxypropyl- $\beta$-cyclodextrin led to increased solubility and phenanthrene toxicity was also reduced thus had improved cometabolic degradation.

Glucose concentration was also determined at different $\mathrm{Cr}(\mathrm{VI})$ concentration at different time interval. Glucose is highly consumed by microbes for their growth and in enhancement of any kind of bacterial activity. Bacterial growth and glucose consumption are inversely proportional to each other. As bacterial growth tends to increase, the glucose consumption also increases because glucose is needed for growth purpose. The similar trend was observed in this study. For Set 1, with doubling of cell number, the glucose consumption increased and was highest at $24 \mathrm{~h}$ when the bacterial growth attended its $\log$ phase, as discussed above. The glucose concentration started declining after $24 \mathrm{~h}$ and it was negligible at $60 \mathrm{~h}$ (Fig. 3A). With decrease in glucose concentration, 


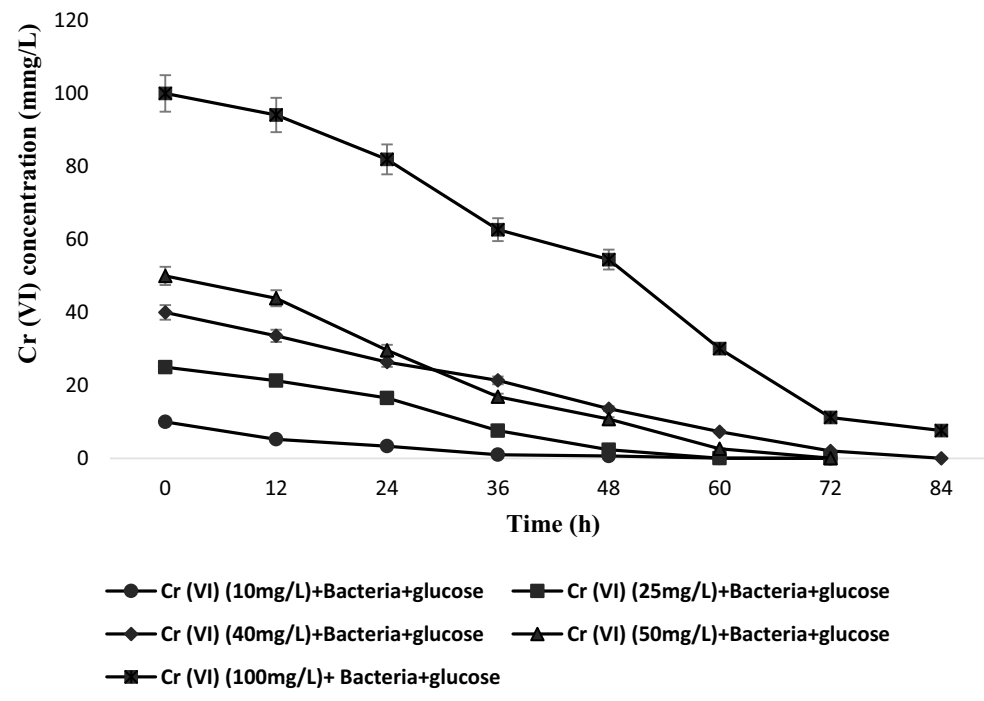

(A)

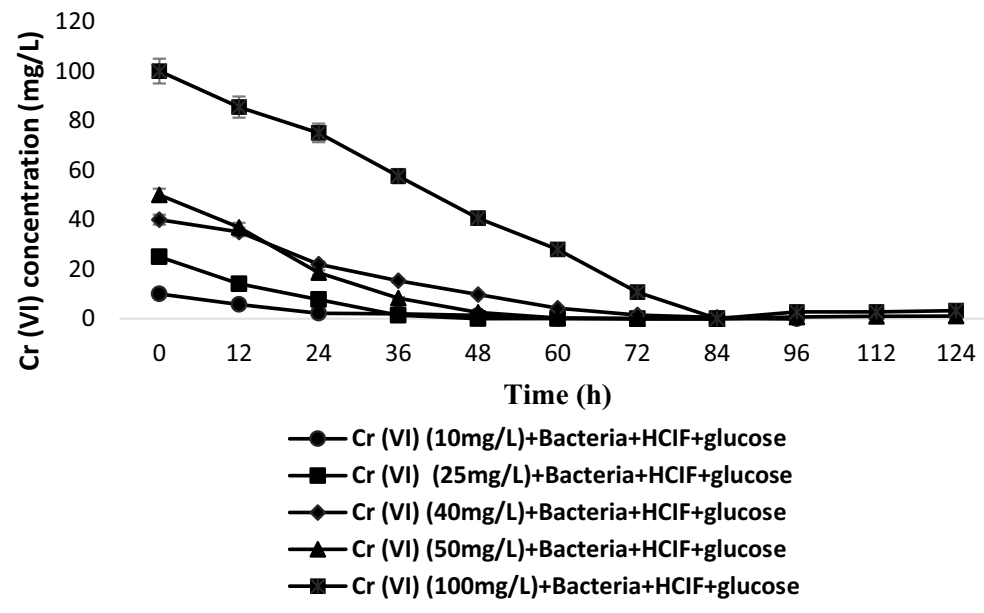

(B)

Figure 2. Changes in $\mathrm{Cr}(\mathrm{VI})$ concentration (A) with glucose as the only substrate (B) with glucose and HCIF as the cometabolic substrate.

the bacterial growth also declined. The limited amount of glucose available for consumption will automatically destroy the population due to competition for limited amount of food source.

In Set 2, the results indicated that glucose concentration declined slowly with respect to time and the complete decline was observed at $120 \mathrm{~h}$ (Fig. 3B).This may be due to the presence of HCIF which also served as a source of growth for microbes, so the glucose consumption in this case was less as compared to set 1 where only glucose was present. As there is presence of two co-metabolic substrate, the burden on substrates may get reduced ${ }^{19}$. The rate kinetics model followed pseudo first order in the case when only glucose was present as substrate (Set 1) and in Set 2 when glucose and HCIF was present as substrates, it followed pseudo second order (Table 1). The rate constant was higher in case of Set 2, when both the substrates were present due to which the $\mathrm{Cr}$ (VI) reduced completely. The rate decreased with increase in $\mathrm{Cr}(\mathrm{VI})$ concentration in both the Sets 1 and 2. One way ANOVA followed by Duncan's post hoc test results confirmed that the results were statistically different (Table 2).

Kinetics of microbial growth in single and tertiary substrate system. The experimentally acquired data for the specific growth rate of the strain at its growth in single substrate system consisting of different chromium concentration as substrate 1 , different glucose concentration as substrate 2 and different HCIF concentration as substrate 3 were used to fit the stated kinetic models using the nonlinear regression analysis in GraphPad Prism 6 software for evaluating the kinetic parameters. Among other inhibitory growth kinetic models, Haldane Andrews's model gave the best fit for the experimentally acquired data for all substrates (Fig. $4 \mathrm{~A}-\mathrm{C}$ ). The $\mathrm{R}^{2}$ value for only chromium as a substrate was found to be $0.977, \mu \max$ value 0.002346 and the inhibition coefficient value to be 134.12. When only glucose was added as a substrate, the $\mu$ max and inhibition coefficient were found to be 0.1129 and 1.01 respectively with $R^{2} 0.9916$. In case of HCIF, the $\mu \max$ and the inhibition coefficient were 0.1923 

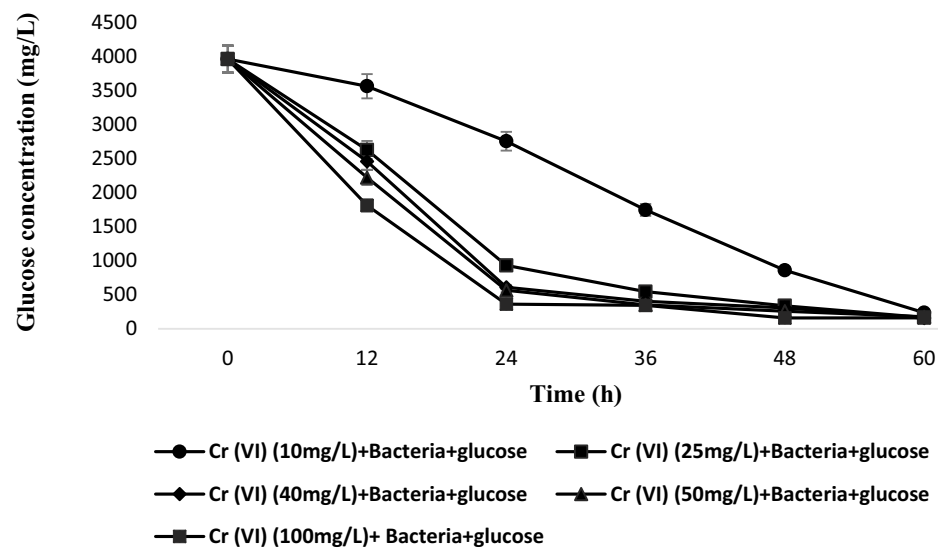

(A)

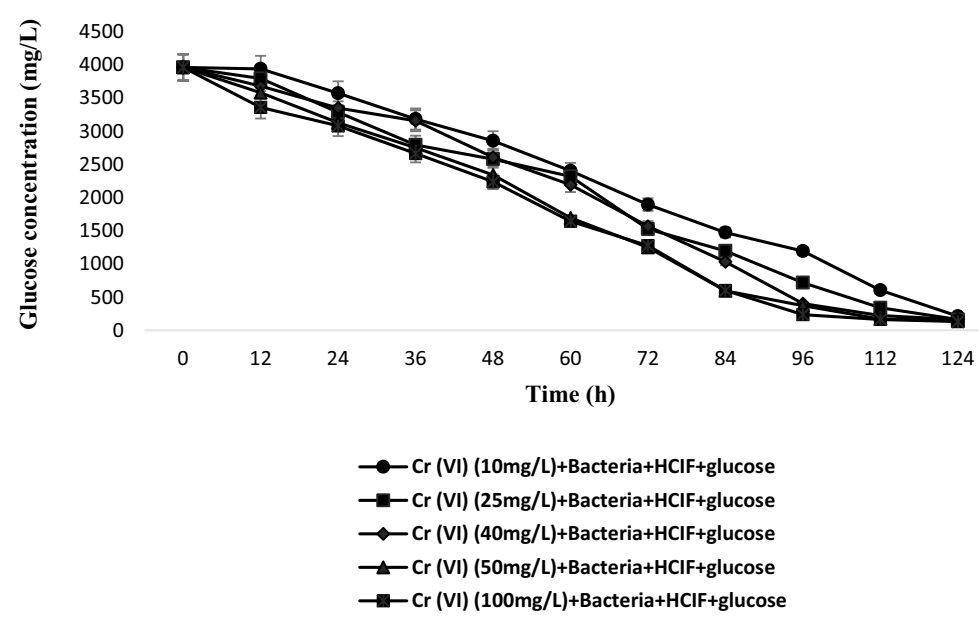

(B)

Figure 3. Comparison of glucose concentration with respect to time (A) in single substrate system (B) in multiple substrate system.

\begin{tabular}{|c|c|c|c|c|}
\hline \multirow[b]{3}{*}{ Experimental combination } & \multicolumn{4}{|c|}{ Kinetics } \\
\hline & \multicolumn{2}{|c|}{$\begin{array}{l}\text { 1st order rate } \\
\text { constant }\left(h^{-1}\right)\end{array}$} & \multicolumn{2}{|c|}{$\begin{array}{l}\text { 2nd order rate } \\
\text { constant }\left(\mathrm{mg}^{-1}\right. \\
\left.\mathbf{L ~ h}^{-1}\right)\end{array}$} \\
\hline & $\mathbf{K}$ & $\mathbf{R}^{2}$ & $\mathbf{K}$ & $\mathbf{R}^{2}$ \\
\hline $\operatorname{Cr}(\mathrm{VI})(10 \mathrm{mg} / \mathrm{L})+$ glucose + bacteria & 0.057 & 0.97 & 0.0306 & 0.8789 \\
\hline $\mathrm{Cr}(\mathrm{VI})(25 \mathrm{mg} / \mathrm{L})+$ glucose + bacteria & 0.0388 & 0.82 & 0.0071 & 0.68 \\
\hline $\operatorname{Cr}(\mathrm{VI})(40 \mathrm{mg} / \mathrm{L})+$ glucose + bacteria & 0.0238 & 0.91 & 0.0017 & 0.78 \\
\hline $\mathrm{Cr}(\mathrm{VI})(50 \mathrm{mg} / \mathrm{L})+$ glucose + bacteria & 0.024 & 0.943 & 0.0015 & 0.88 \\
\hline $\mathrm{Cr}(\mathrm{VI})(100 \mathrm{mg} / \mathrm{L})+$ glucose + bacteria & 0.0119 & 0.938 & 0.0002 & 0.88 \\
\hline $\mathrm{Cr}(\mathrm{VI})(10 \mathrm{mg} / \mathrm{L})+$ glucose + bacteria $+\mathrm{HCIF}$ & 0.0139 & 0.9306 & 0.046 & 0.954 \\
\hline $\mathrm{Cr}(\mathrm{VI})(25 \mathrm{mg} / \mathrm{L})+$ glucose + bacteria $+\mathrm{HCIF}$ & 0.0037 & 0.729 & 0.126 & 0.969 \\
\hline $\mathrm{Cr}(\mathrm{VI})(40 \mathrm{mg} / \mathrm{L})+$ glucose + bacteria + HCIF & 0.0016 & 0.892 & 0.0426 & 0.909 \\
\hline $\mathrm{Cr}(\mathrm{VI})(50 \mathrm{mg} / \mathrm{L})+$ glucose + bacteria $+\mathrm{HCIF}$ & 0.0029 & 0.868 & 0.0695 & 0.928 \\
\hline $\mathrm{Cr}(\mathrm{VI})(100 \mathrm{mg} / \mathrm{L})+$ glucose + bacteria $+\mathrm{HCIF}$ & 0.0004 & 0.852 & 0.0236 & 0.9118 \\
\hline
\end{tabular}

Table 1. Kinetic analysis for different substrate systems. 


\begin{tabular}{|l|c|l|l|l|r|}
\hline $\begin{array}{l}\text { Biomass } \\
\text { concentration }\end{array}$ & $\mathbf{1 2 ~ \mathbf { ~ }}$ & $\mathbf{2 4} \mathbf{~ h}$ & $\mathbf{3 6} \mathbf{h}$ & $\mathbf{4 8} \mathbf{~ h}$ & $\mathbf{6 0} \mathbf{~}$ \\
\hline Biotic control & $0.144 \pm 0.125 \mathrm{a}$ & $0.691 \pm 0.1634 \mathrm{a}$ & $1.417 \pm 0.374 \mathrm{a}$ & $2.203 \pm 0.061 \mathrm{a}$ & $2.86233 \pm 0.080 \mathrm{a}$ \\
\hline $10 \mathrm{mg} / \mathrm{L}$ & $0.139 \pm 0.014 \mathrm{a}$ & $0.204 \pm 0.003 \mathrm{bc}$ & $0.309333 \pm 0.028919 \mathrm{~b}$ & $0.612333 \pm 0.035796 \mathrm{~b}$ & $0.4573 \pm 0.057002 \mathrm{~b}$ \\
\hline $25 \mathrm{mg} / \mathrm{L}$ & $0.154667 \pm 0.066154 \mathrm{a}$ & $0.232444 \pm 0.021461 \mathrm{bc}$ & $0.095822 \pm 0.026619 \mathrm{c}$ & $0.042578 \pm 0.01024 \mathrm{~d}$ & $0.029522 \pm 0.005303 \mathrm{c}$ \\
\hline $40 \mathrm{mg} / \mathrm{L}$ & $0.056667 \pm 0.015275 \mathrm{~b}$ & $0.266 \pm 0.012 \mathrm{~b}$ & $0.131 \pm 0.009849 \mathrm{c}$ & $0.145333 \pm 0.049075 \mathrm{c}$ & $0.02287 \pm 0.001499 \mathrm{c}$ \\
\hline $50 \mathrm{mg} / \mathrm{L}$ & $0.030489 \pm 0.004575 \mathrm{~b}$ & $0.059444 \pm 0.017519 \mathrm{c}$ & $0.038778 \pm 0.014206 \mathrm{c}$ & $0.049667 \pm 0.027099 \mathrm{~d}$ & $0.026333 \pm 0.005774 \mathrm{c}$ \\
\hline $100 \mathrm{mg} / \mathrm{L}$ & $0.019667 \pm 0.002309 \mathrm{~b}$ & $0.258778 \pm 0.213544 \mathrm{~b}$ & $0.106611 \pm 0.131977 \mathrm{c}$ & $0.076889 \pm 0.019357 \mathrm{~d}$ & $0.017444 \pm 0.001711 \mathrm{c}$ \\
\hline
\end{tabular}

Table 2. One way ANOVA analysis. All values are represented as mean \pm SD. Different alphabets represents difference in mean according to one way ANOVA followed by Duncan's post hoc test at probability level $(\mathrm{p} \leq 0.05)$.

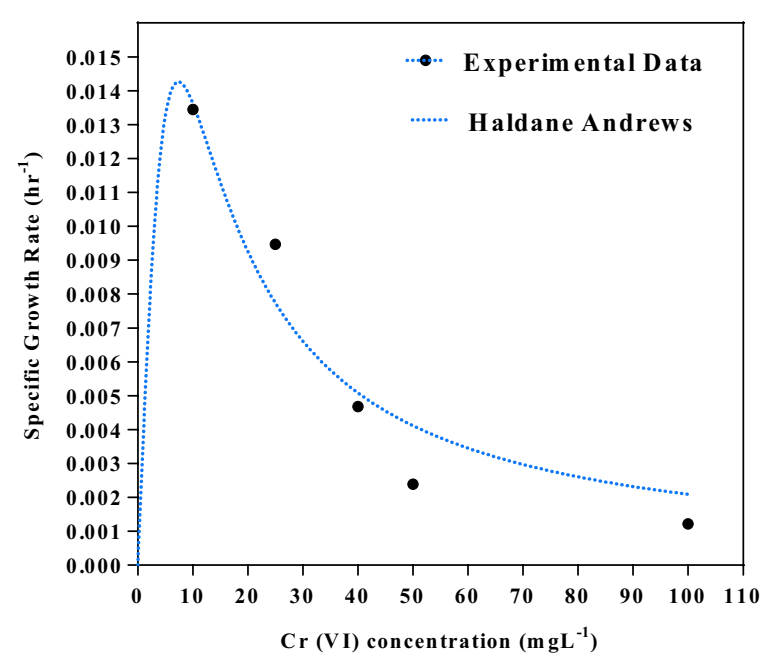

(A)

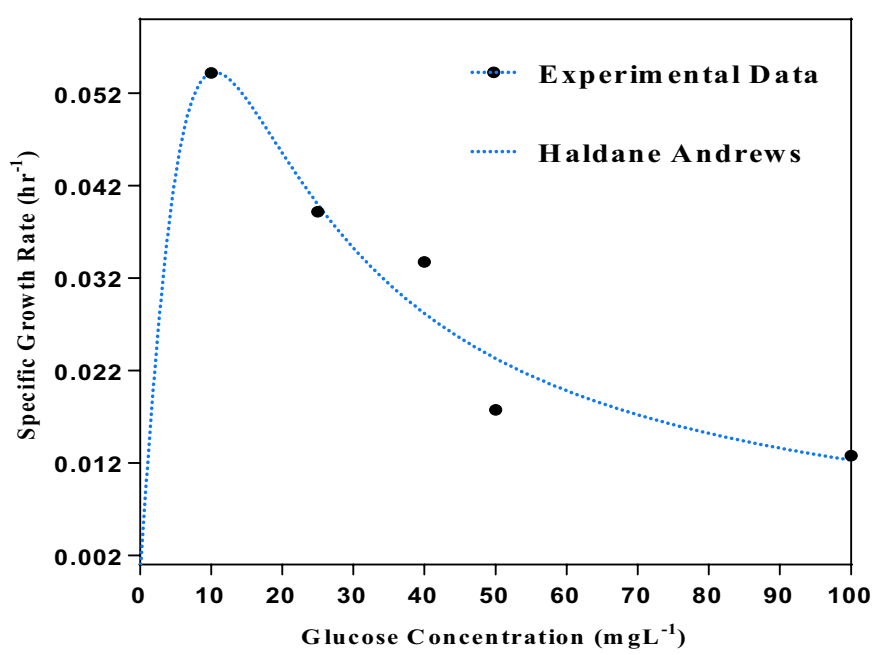

(B)

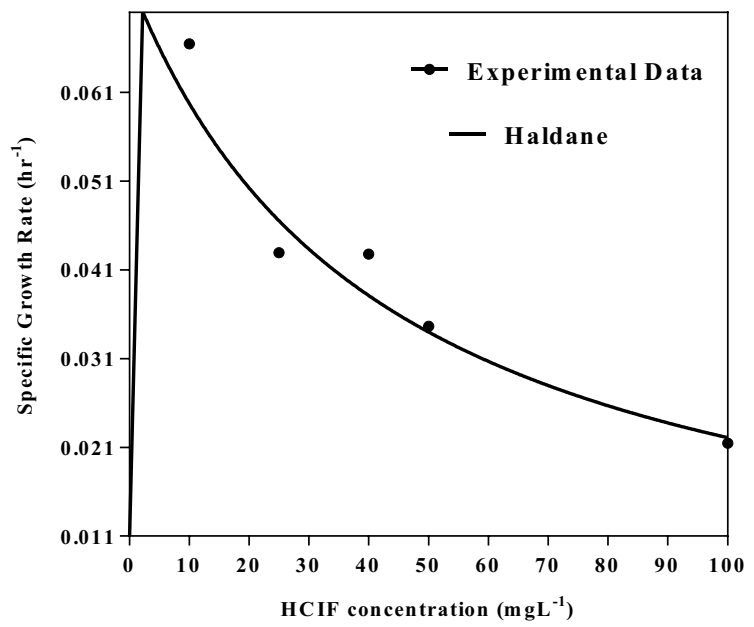

(C)

Figure 4. Growth Kinetics modeling in single substrate system (A) with respect to $\mathrm{Cr}(\mathrm{VI})$ concentration, (B) glucose concentration, (C) HCIF concentration.

and 11.99 respectively and $\mathrm{R}^{2}$ value was 0.9876 . The values of specific growth rate obtained from fitting the values of single substrate system was later applied to the various inhibitory growth models to check for the cometabolic activity in tertiary substrate system.

Out of the other inhibitory models used for fitting, Monod model was best fitted for the growth kinetics in tertiary substrate system in order to evaluate the interaction between the three co-metabolic substrate (i.e. $\mathrm{HCIF}$ and glucose and chromium) in enhancing $\mathrm{Cr}(\mathrm{VI})$ reduction. Previous studies ${ }^{31}$ showed that addition of some co-metabolic substrate to the system was effective in dealing the degradation of refractory compounds. 


\begin{tabular}{|c|c|c|c|c|c|}
\hline \multirow[b]{2}{*}{ Kinetic constants } & \multicolumn{5}{|c|}{ Different $\mathrm{Cr}(\mathrm{VI})$ concentration } \\
\hline & $10 \mathrm{mg} / \mathrm{L}$ & $25 \mathrm{mg} / \mathrm{L}$ & $40 \mathrm{mg} / \mathrm{L}$ & $50 \mathrm{mg} / \mathrm{L}$ & $100 \mathrm{mg} / \mathrm{L}$ \\
\hline$K_{2 C} S_{P}$ & 0.287 & 0.655 & 0.834 & 0.761 & 0.934 \\
\hline$K_{3 C} S_{h}$ & 0.015 & 0.047 & 0.062 & 0.059 & 0.114 \\
\hline$K_{4 C} S_{P} S_{h}$ & 0.0249 & 0.068 & 0.083 & 0.061 & 0.154 \\
\hline$K_{2 P} S_{C}$ & 0.586 & 1.221 & 1.146 & 1.452 & 1.625 \\
\hline$K_{3 P} S_{h}$ & 0.489 & 0.812 & 0.741 & 1.332 & 1.524 \\
\hline$K_{4 P} S_{C} S_{h}$ & 0.04 & 0.042 & 0.092 & 0.289 & 0.451 \\
\hline$K_{2 h} S_{C}$ & 0.017 & 0.052 & 0.035 & 0.124 & 0.1 \\
\hline$K_{3 h} S_{P}$ & 0.08 & 0.094 & 0.103 & 0.121 & 0.267 \\
\hline$K_{4 h} S_{C} S_{P}$ & 0.041 & 0.057 & 0.1149 & 0.201 & 0.415 \\
\hline
\end{tabular}

Table 3. Growth kinetic parameters of Serrtia sp. for tertiary substrate system.

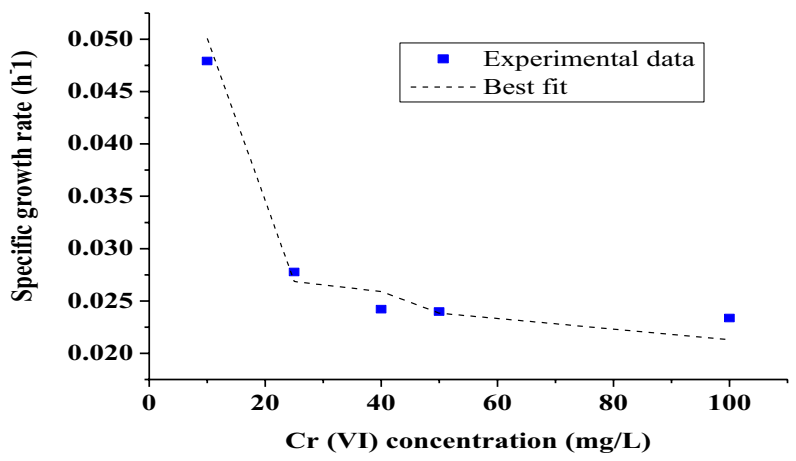

Figure 5. Growth kinetic modelling in tertiary substrate system.

To understand the co-metabolism between glucose, $\mathrm{Cr}(\mathrm{VI})$ and HCIF in the tertiary system, Eq. (3) was used for the cell growth kinetic analysis. The relative kinetic parameters obtained from the analysis are presented in Table 3.The model was best fitted with the $\mathrm{R}^{2}$ value of 0.988 (Fig. 5).

The values of $\mathrm{K}_{2} \mathrm{CS}_{\mathrm{P}}$ (Inhibition of glucose in the presence of $\mathrm{Cr}(\mathrm{VI})$ ), $\mathrm{K}_{3} \mathrm{C} \mathrm{S}_{\mathrm{h}}$ (Inhibition of glucose in the presence of $\mathrm{HCIF}$ ) and $\mathrm{K}_{4} \mathrm{C} \mathrm{S}_{\mathrm{P}} \mathrm{S}_{\mathrm{h}}$ (Inhibition of glucose in the presence of $\mathrm{Cr}(\mathrm{VI})$ and HCIF) increased with increasing $\mathrm{Cr}(\mathrm{VI})$ concentration. Amongst the three kinetic constants, the value of $\mathrm{K}_{3} \mathrm{C}_{\mathrm{h}}$ is lower as compared to $\mathrm{K}_{4} \mathrm{C} \mathrm{S}_{\mathrm{P}} \mathrm{S}_{\mathrm{h}}$ and $\mathrm{K}_{2} \mathrm{C} \mathrm{S}_{\mathrm{P}}$. Lower values of $\mathrm{K}_{3} \mathrm{C} \mathrm{S}_{\mathrm{h}}$, indicates that the inhibition of glucose consumption is low in presence of HCIF due to the fact that HCIF was also providing food source for the microbial growth other than glucose. The values of $\mathrm{K}_{2} \mathrm{C} \mathrm{S}_{\mathrm{p}}$ and $\mathrm{K}_{4} \mathrm{CS}_{\mathrm{p}} \mathrm{S}_{\mathrm{h}}$ revealed that when only $\mathrm{Cr}$ was present $\left(\mathrm{K}_{2} \mathrm{C} \mathrm{S}_{\mathrm{p}}\right)$ the inhibition on glucose consumption was higher as compared to when both $\mathrm{Cr}$ and $\mathrm{HCIF}\left(\mathrm{K}_{4} \mathrm{C} \mathrm{S}_{\mathrm{P}} \mathrm{S}_{\mathrm{h}}\right)$ were present. Similarly, amongst the other three kinetic constant values $\mathrm{K}_{2} \mathrm{P} \mathrm{S}_{\mathrm{C}}$ (Inhibition of $\mathrm{Cr}(\mathrm{VI})$ reduction in the presence of glucose), K3P Sh (Inhibition of $\mathrm{Cr}(\mathrm{VI})$ reduction in the presence of $\mathrm{HCIF}$ ) and $\mathrm{K}_{4} \mathrm{P} \mathrm{S}_{\mathrm{P}} \mathrm{S}_{\mathrm{C}}$ (Inhibition of $\mathrm{Cr}(\mathrm{VI})$ reduction in the presence of glucose and $\mathrm{HCIF}$ ), $\mathrm{K}_{2} \mathrm{P}_{\mathrm{C}}$ values were higher which indicates that when only glucose was present $\left(\mathrm{K}_{2} \mathrm{P} \mathrm{S}_{\mathrm{C}}\right)$ inhibition on $\mathrm{Cr}$ reduction was higher followed by inhibition on Cr reduction when only HCIF was present $\left(\mathrm{K}_{3} \mathrm{P} \mathrm{S}_{\mathrm{h}}\right)$. But when both substrates (glucose and HCIF) were present $\left(\mathrm{K}_{4} \mathrm{P} \mathrm{S}_{\mathrm{P}} \mathrm{S}_{\mathrm{C}}\right)$, the inhibition on $\mathrm{Cr}$ reduction was lowest. Inhibition of HCIF consumption due to glucose $\left(\mathrm{K}_{2} \mathrm{~h} \mathrm{~S}_{\mathrm{C}}\right)$ is lowest as compared to inhibition of HCIF consumption in presence of both $\mathrm{Cr}$ and glucose $\left(\mathrm{K}_{4} \mathrm{~h} \mathrm{~S}_{\mathrm{P}} \mathrm{S}_{\mathrm{C}}\right)$ and when only Cr was present $\left(\mathrm{K}_{3} \mathrm{~h} \mathrm{~S}_{\mathrm{P}}\right)$. When HCIF and glucose were present, microbes were utilizing both glucose and HCIF for their growth. The higher values of $\mathrm{K}_{2} \mathrm{P}$ and $\mathrm{K}_{3} \mathrm{P}$ suggested high degree of inhibition of glucose and $\mathrm{HCIF}$ on $\mathrm{Cr}(\mathrm{VI})$ reduction and diauxic growth of the strain. Similarly lower values of $\mathrm{K}_{2} \mathrm{C}$ and $\mathrm{K}_{3} \mathrm{C}$ indicated the negligible impact of $\mathrm{Cr}(\mathrm{VI})$ imposed to glucose and HCIF consumption. It has been studied by ${ }^{32}$ that for the growth of cell on mixed substrates, there are categorization of the interaction between the growth substrates which is defined as competitive, noncompetitive and uncompetitive inhibition of growth. On the basis of these observations, the results showed that glucose and $\mathrm{Cr}(\mathrm{VI})$ were not structurally similar, so uncompetitive inhibition was the best interpretation to the interaction between glucose and $\mathrm{Cr}(\mathrm{VI})$. The interaction constants $\mathrm{K}_{2} \mathrm{~h}$ and $\mathrm{K}_{3} \mathrm{~h}$ (inhibition of iron due to glucose and $\mathrm{Cr}(\mathrm{VI})$ respectively) were one to threefold larger than the corresponding $\mathrm{K}_{2} \mathrm{C}$ and $\mathrm{K}_{3} \mathrm{C}$. Thus it can be inferred that another possible mixed pattern of interaction exists involving both competitive and uncompetitive inhibition. The values of kinetic constants $\mathrm{K}_{4} \mathrm{C}, \mathrm{K}_{4} \mathrm{P}$ and $\mathrm{K}_{4} \mathrm{~h}$ indicated that $\mathrm{K}_{4} \mathrm{P}$ and $\mathrm{K}_{4} \mathrm{~h}$ values are lower as compared to the value of $\mathrm{K}_{4} \mathrm{C}$. This may be due to the reason that the inhibition factor was more in case when there were presence of $\mathrm{Cr}$ and HCIF which poses competitive inhibition. The results confirmed that both glucose and HCIF as a co-metabolic substrate had a great role in $\mathrm{Cr}(\mathrm{VI})$ reduction, but when HCIF was added as another substrate, it increased the reduction efficiency of the system. The strain utilized glucose as well as 
HCIF for maintaining their activity and for their growth. It has been reported by ${ }^{33,34}$ that two substrates (glucose and biphenyl) had great role in bioremediation of PBDEs. However, a large number of reports ${ }^{35}$ indicated that optimum dose of co-substrates is essential to use because excessive dose of any of the co-substrates hampers the degradation efficiency and was attributed for the inhibition between the substrates. Excess dosage of substrates would cause self-inhibition on growth of the cell, thus decrease reduction efficiency. Therefore, it is extremely important to choose appropriate co-substrate and optimum dosage of substrate.

\section{Conclusion}

The efficiency of $\mathrm{Cr}(\mathrm{VI})$ reduction by Serratia sp. was improved by cometabolism activity. Meanwhile, it is known that presence of diversity of carbon sources impose effects on the interactive activity of metabolic pathways and substrates. Glucose had great role as anti-competitive inhibitor in $\mathrm{Cr}(\mathrm{VI})$ reduction. However, on the other side, another substrate HCIF had both competitive and uncompetitive inhibition on $\mathrm{Cr}(\mathrm{VI})$ reduction by enhancing the strain ability to help in complete reduction. Both glucose and HCIF as a co-metabolic substrate had a great role in $\mathrm{Cr}(\mathrm{VI})$ reduction, but when HCIF was added as another substrate, it increased the reduction efficiency of the system and combination of HCIF and glucose showed least inhibition to hexavalent chromium reduction by Serratia sp. The outcomes of the current work enlightens a noteworthy approach to carry out treatment of other compounds as well and a great finding for enhancing long term performance of ZVI PRBs in combination with Serratia Sp. for remediation of $\mathrm{Cr}(\mathrm{VI})$ contaminated sites.

Received: 19 January 2021; Accepted: 31 March 2021

Published online: 25 May 2021

\section{References}

1. Sathvikaa, T. et al. A co-operative endeavor by nitrifying bacteria Nitrosomonas and Zirconium based metal organic framework to remove hexavalent chromium. Chem. Eng. J. 360, 879-889 (2019).

2. Pradhan, D., Sukla, L. B., Sawyer, M. \& Rahman, P. K. S. M. Recent bioreduction of hexavalent chromium in wastewater treatment: A review. J. Ind. Eng. Chem. 55, 1-20 (2017).

3. Wua, M. et al. Bioreduction of hexavalent chromium using a novel strain CRB-7 immobilized on multiple materials. J. Hazard. Mater. 368, 412-420 (2019).

4. Di Palma, L., Verdone, N. \& Vilardi, G. Kinetic modeling of Cr(VI) reduction by nZVI in soil: The influence of organic matter and manganese oxide. Bull. Environ. Contam. Toxicol. 101(6), 692-697 (2018).

5. Brasili, E. et al. Remediation of hexavalent chromium contaminated water through zero-valent iron nanoparticles and effects on tomato plant growth performance. Sci. Rep. 10(1), 1-11 (2020).

6. Lin, C. J. et al. Chromate reduction by zero-valent Al metal as catalyzed by polyoxometalate. Water Res. 43, 5015-5022 (2009).

7. Mpouras, T., Polydera, A., Dermatas, D., Verdone, N. \& Vilardi, G. Multi wall carbon nanotubes application for treatment of Cr (VI)-contaminated groundwater; Modeling of batch \& column experiments. Chemosphere 269, 128749 (2020).

8. Scharf, B. et al. Molecular analysis of chromium and cobalt-related toxicity. Sci. Rep. 4, 5729 (2014).

9. Desai, C., Jain, K. \& Madamwar, D. Evaluation of in vitro $\mathrm{Cr}(\mathrm{VI})$ reduction potential in cytosolic extracts of three indigenous Bacillus sp. isolated from Cr(VI) polluted industrial landfill. Bioresour. Technol. 99, 6059-6069 (2008).

10. Srivastava, S., Yadav, G. K., Sinha, A. \& Mishra, B. K. Comparative study for reduction of hexavalent chromium by high carbon iron filings (HCIF) and electrolytic Iron:mass transfer limitations. Asian. J. Chem. 27(4), 1398-1402 (2014).

11. Banerjeea, S., Misraa, A., Chaudhury, S. \& Dama, B. A Bacillus strain TCL isolated from Jharia coalmine with remarkable stress responses, chromium reduction capability and bioremediation potential. J. Hazard. Mater. 367, 215-223 (2019).

12. Gong, K. et al. Ultrasonic pretreated sludge derived stable magnetic active carbon for Cr (VI) removal from wastewater. ACS Sustain. Chem. Eng. 6(6), 7283-7291 (2018).

13. Huang, J. et al. Hexavalent chromium removal over magnetic carbon nanoadsorbents: Synergistic effect of fluorine and nitrogen co-doping. J. Mater. Chem. A 6(27), 13062-13074 (2018).

14. Singh, R., Kumar, M. \& Bishnoi, N. R. Development of biomaterial for chromium (VI) detoxification using Aspergillus flavus system supported with iron. Ecol. Eng. 91, 31-40 (2016).

15. Arévalo-Rangel, D. L., Cárdenas-González, J. F., Martínez-Juárez, V. M. \& Acosta-Rodríguez, I. Hexavalent chromate reductase activity in cell free extracts of Penicillium sp. Bioinorg. Chem. Appl. https://doi.org/10.1155/2013/909412 (2013).

16. Robins, K. J., Hooks, D. O., Rehm, B. H. \& Ackerley, D. F. Escherichia coli NemA is an efficient chromate reductase that can be biologically immobilized to provide a cell free system for remediation of hexavalent chromium. PLoS ONE 8(3), 59-200 (2013).

17. Ge, S., Ge, S., Zhou, M. \& Dong, X. Bioremediation of hexavalent chromate using permeabilized Brevibacterium sp. and Stenotrophomonas sp. cells. J. Environ. Manag. 157, 54-59 (2015).

18. Qu, M. et al. Bioremediation of hexavalent chromium contaminated soil by a bioleaching system with weak magnetic fields. Int. Biodeterior. Biodegrad. 128, 41-47 (2018).

19. Lv, Y. C., Li, L. H., Chen, Y. C., Tang, Z. H. \& Hu, Y. Y. Effects of glucose and biphenyl on aerobic cometabolism of polybrominated diphenylethers by Pseudomonas putida: Kinetics and degradation mechanism. Int. Biodeterior. Biodegrad. 108, 76-84 (2016).

20. Zhoua, J. et al. Cometabolic degradation of low-strength coking wastewater and the bacterial community revealed by highthroughput sequencing. Bioresour. Technol. 245, 379-385 (2017).

21. Jamshidian, H., Khatami, S., Mogharei, A., Vahabzadeha, F. \& Nickzad, A. Cometabolic degradation of para-nitrophenol and phenol by Ralstonia eutropha in a Kissiris immobilized cell bioreactor. Korean J. Chem. Eng. 30(11), 2052-2058 (2013).

22. Shi, S., Qu, Y., Zhou, H., Ma, Q. \& Ma, F. Characterization of a novel cometabolic degradation carbazole pathway by a phenolcultivated Arthrobacter sp. W1. Bioresour. Technol. 193, 281-287 (2015).

23. Heidari, H., Sedighi, M., Zamir, S. M. \& Shojaosadati, S. A. Bisphenol A degradation by Ralstonia eutropha in the absence and presence of phenol. Int. Biodeterior. Biodegrad. 119, 37-42 (2017).

24. Wang, W. et al. Performance robustness of the UASB reactors treating saline phenolic wastewater and analysis of microbial community structure. J. Hazard. Mater. 331, 21-27 (2017).

25. Upadhyay, S., Tarafdar, A. \& Sinha, A. Assessment of Serratia sp. isolated from iron ore mine in hexavalent chromium reduction: kinetics, fate and variation in cellular morphology. Environ. Technol. 41(9), 1117-1126. https://doi.org/10.1080/09593330.2018. 1521875 (2020).

26. Jiang, C., Xu, X., Megharaj, M., Naidu, R. \& Chen, Z. Inhibition or promotion of biodegradation of nitrate by Paracoccus sp. in the presence of nanoscale zero-valent iron. Sci. Total Environ. 530, 241-246 (2015).

27. Das, A. P. \& Mishra, S. Biodegradation of the metallic carcinogen hexavalent chromium Cr (VI) by an indigenously isolated bacterial strain. J. Carcinog. 9(6). https://doi.org/10.4103/1477-3163.63584 (2010). 
28. Shi, Z. et al. Hexavalent chromium removal by a new composite system of dissimilatory iron reduction bacteria Aeromonas hydrophila and nanoscale zero-valent iron. Chem. Eng. J. 362, 63-70 (2019).

29. Ye, C., Ching, T. H., Yoza, B. A., Masutani, S. \& Li, Q. X. Cometabolic degradation of blended biodiesel by Moniliella wahieum Y12T and Byssochlamys nivea M1. Int. Biodeterior. Biodegrad. 125, 166-169 (2017).

30. Xiao, M. et al. Effect of hydroxypropyl- $\beta$-cyclodextrin on the cometabolism of phenol and phenanthrene by a novel Chryseobacterium sp. Bioresour. Technol. 273, 56-62 (2019).

31. Field, J. A. \& Sierra-Alvarez, R. Microbial transformation and degradation of polychlorinated biphenyls. Environ. Pollut. 155(1), $1-12(2008)$.

32. Kargi, F. \& Shuler, M. L. Bioprocess Engineering: Basic Concepts (Prentice-Hall PTR, 1992).

33. Lu, M. et al. Biodegradation of decabromodiphenyl ether (BDE-209) by a metal resistant strain, Bacillus cereus JP12. Bioresour. Technol. 149, 8-15 (2013).

34. Shi, G. et al. Aerobic biotransformation of decabromodiphenyl ether (PBDE-209) by Pseudomonas aeruginosa. Chemosphere 93(8), 1487-1493 (2013).

35. Xin, J., Liu, X., Liu, W. \& Zheng, X. L. Aerobic transformation of BDE-47 by a Pseudomonas putida sp. strain TZ-1 isolated from PBDEs-contaminated sediment. Bull. Environ. Contam. Toxicol. 93(4), 483-488 (2014).

\section{Author contributions}

S.U. did the experimentation, modeling and wrote the manuscript. A.S. conceptualized and guided the whole work and edited final manuscript.

\section{Competing interests}

The authors declare no competing interests.

\section{Additional information}

Correspondence and requests for materials should be addressed to A.S.

Reprints and permissions information is available at www.nature.com/reprints.

Publisher's note Springer Nature remains neutral with regard to jurisdictional claims in published maps and institutional affiliations.

(c) (i) Open Access This article is licensed under a Creative Commons Attribution 4.0 International License, which permits use, sharing, adaptation, distribution and reproduction in any medium or format, as long as you give appropriate credit to the original author(s) and the source, provide a link to the Creative Commons licence, and indicate if changes were made. The images or other third party material in this article are included in the article's Creative Commons licence, unless indicated otherwise in a credit line to the material. If material is not included in the article's Creative Commons licence and your intended use is not permitted by statutory regulation or exceeds the permitted use, you will need to obtain permission directly from the copyright holder. To view a copy of this licence, visit http://creativecommons.org/licenses/by/4.0/.

(C) The Author(s) 2021 